\title{
Growth performance of local and genetically improved chicken of Bangladesh
}

\author{
A Akhter ${ }^{1}$, SC Das ${ }^{1}$, MS Hasan ${ }^{1}$, T Akter $^{1}$, M Sultana ${ }^{1}$, S Faruque $^{2}$, MA Rashid ${ }^{2}$, B Dey ${ }^{1}$, MA \\ Hossain $^{1}$, S Akter ${ }^{1}$ and NN Retee ${ }^{1}$
}

${ }^{1}$ Department of Poultry Science, Faculty of Animal Husbandry, Bangladesh Agricultural University, Mymensingh 2202, Bangladesh; ${ }^{2}$ Bangladesh Livestock Research Institute, Savar, Dhaka, Bangladesh

\begin{abstract}
The experiment was conducted to compare the growth performance among four genotypes of indigenous chicken namely Non-descriptive Native (ND), genetically Improved Native (IN), Hilly (HC) and Naked Neck (NN) of Bangladesh under free-range rearing system. A total of 288 day old chicks (DOC) from four genotypes were divided into four treatments having eight replications of each for a period of 12 weeks under free-range system with supplementation of commercial broiler diet. During first 4 weeks, all chicks were kept together, whereas chicks of ND was brooded in the same room but separated by a partition. At 5 weeks of age chicks were randomly distributed to the selected farmers. Growth parameters were recorded to determine the comparative growth performance among four genotypes of chicken. The highest body weight (1110.76 g/bird) was achieved by HC, followed by IN $(900.63 \mathrm{~g} / \mathrm{bird})$ and NN (831.13 g/bird) at 12 weeks of age. The lowest body weight $(734.13 \mathrm{~g} / \mathrm{bird})$ however was found in ND chicken. During the growing period under free range rearing (5-12 weeks), HC group consumed the highest amount of feed $(2697.02 \mathrm{~g} / \mathrm{bird})$ with an average FCR of 3.06 while the lowest feed consumption ( $2666.13 \mathrm{~g} / \mathrm{bird}$ ) with the highest FCR of 4.90 was observed in ND. IN consumed ( $2674.63 \mathrm{~g} / \mathrm{bird}$ ) feed with an average FCR of 3.92 and BLRI improved NN consumed ( $2668.13 \mathrm{~g} / \mathrm{bird}$ ) feed with an average FCR of 4.19. Live weight gains in all the four genotypes of indigenous chicken were changed almost in a similar pattern. Significant differences were observed in live weight, dressing percentage, breast meat, drumstick, thigh meat among the four genotypes of chicken. The HC was superior to other genotypes of indigenous chicken including ND in terms of growth performance, meat yield characteristics and net returns.
\end{abstract}

Key words: native chicken, supplementary feeding, scavenging system, growth performance

Bangladesh Animal Husbandry Association. All rights reserved.

Bang. J. Anim. Sci. 2018. 47 (2):76-84

\section{Introduction}

Indigenous chickens are genetically nondescriptive types, plays pivotal role in household nutrition and serve generating source for the rural poor families in most countries of Asia, Africa and Latin America (Norris et al. 2007 and Swatson et al. 2001). Compared to modern commercial broiler and layer, rearing of indigenous chicken appears to be the best choice of most rural poor farmers as because of their low feed cost, better disease resistance capability, premier meat and egg quality and also minimum production cost (Singh et al. 2011). Further the birds have ability to survive in harsh rural situations where feed is scarce, housing and medication facilities are inadequate or improper and also having large tolerance to heat stress (Das et al. 2008).
Indigenous chicken are considered as good scavenger and therefore receive major portion of their food from natural resources (Sonaiya et al. 2004). In Bangladesh, the average number of chicken per household was recorded as 7.0 and the national sharing of commercial poultry to its indigenous counterpart in terms of egg production is almost equal i.e. 50:50 and that of meat production is 60:40 (Islam et al. 2015). Meat and egg qualities of indigenous chicken are unique and well accepted by all classes of people throughout the world. The special characteristic of smell, taste and texture may be attributed in the meat and egg as because the indigenous chicken consumed varieties of feed ingredients, some are known and some are still unknown, during foraging at the farmer's homestead areas (Chowdhury, 2013). The consumer preferred indigenous chicken meat and egg for decade after decade and

*Corresponding author: das_poultry@yahoo.com 
consumer's attraction towards indigenous chicken will also remain unchanged in future as because of their special smell, taste and texture (Mengesha, 2012, Das et al. 2014 and Chowdhury, 2013). On the contrary, importation of high yielding grandparent or parent strains for meat production is not only dollar drain but also their meat quality usually considered inferior by the both local and urban consumers compared to indigenous chicken meat. Market price of indigenous chicken meat is therefore 2-3 times higher than the commercial broiler this is because of special preference of the consumers. Further, consumer's attitude towards the commercial broiler meat is changing day by day because of safety food concern. Consumer's purchasing capability is likely to be increased in the forthcoming days in advancement with the country's economic growth, and therefore consumers in future may be more aware of regarding the safety and quality aspects of poultry meat along with many other agricultural food products. Under such circumstances, improvement of growth and production of indigenous chicken may have significance to satisfy the consumer's demand on safe and quality poultry meat.

Keeping all above points in consideration, Bangladesh Livestock Research Institute (BLRI) initiated a program since 1984 for the conservation and development of indigenous chicken through several poultry development projects (Faruque et al. 2016). To achieve the goal, a foundation stock of indigenous chicken was established in 2010 utilizing the existing stock of BLRI as well as by incorporating variation through screening of male/female/eggs from wider indigenous chicken gene pool of Bangladesh. As a consequence, BLRI claimed to develop few stocks of indigenous chicken using available genotypes showing better egg and meat production performance which has been termed as BLRI improved native chicken. These improved stocks are developed using three local genotypes such as Non-descriptive Native Chicken (NC), Hilly Chicken (HC) and Naked Neck (NN), which have been developed in intensive management system. Growth performance of the BLRI improved three local genotypes, their feed efficiency, adaptable capability and meat quality characteristics under scavenging rearing system in rural farmer's homestead is yet unknown. Improvement of the above mentioned three genotypes were finally compared with Nondescriptive Native (ND). The present study was therefore undertaken into examine the growth performance and carcass characteristics of Nondescriptive Native (ND), Improved stock of Native Chicken (IN), Hilly Chicken (HC) and Naked Neck (NN) under free range rearing with supplementation of commercial feed.

\section{Materials and Methods}

The total experimental period were spilt out into two phases: first the brooding period $(0-4$ weeks) where the DOC of three BLRI improved indigenous chicken genotypes were kept together and data were recorded accordingly. DOCs of non-descriptive native were brooded separately. Secondly, after completion of brooding period in confinement, all the experimental birds were distributed to the selected farmers, where birds were kept in scavenging rearing system with a night shelter for the remaining experimental period i.e. 5-12 weeks of age.

A total of 288 day old chicks of four chicken genotypes namely Non-descriptive native (ND), Improved stock of Native Chicken (IN), Hilly Chicken (HC) and Naked Neck (NN) were collected from BLRI, Savar, Dhaka and brought them to Nakla upazila under Sherpur district. All the chicks were kept in confined initial 4 weeks for brooding and then they were distributed to the selected farmers. After completion the brooding period, chicks were randomly allocated to four treatments (4 chicken genotypes) having 72 birds in each. Each treatment further divided into eight replications (farmers) i.e. nine birds in each replication (farmer). The enthusiastic farmers who have homestead area for scavenging chicks were selected. Special attention was given to involve rural women in care and management of birds as they are usually more devoted to perform these activities compared to man. To observe the growth performance and other parameters, experiment was conducted for 8 weeks at farmers homestead under scavenging system.

\section{Preparation of experimental house, brooding and rearing of chicks}

An open sided semi gable type house with concrete floor was used for brooding the DOC. The house was partitioned into two rooms, one for BLRI improved chicks (Improved Native, Hilly and Naked Neck) and one for local indigenous chicks. The partitions were made of galvanized wire net, covered by jute cloth. Dayold chicks were individually weighed and legbanded. Chicks were placed under the brooder which were cleaned and disinfected earlier. All feeders, waterers and other necessary equipment were also properly cleaned, washed and disinfected before placement of the experimental chicks. Since the DOCs were brought to the experimental site after a long journey, $5 \%$ glucose solution and multivitamins were supplied soon after arrival. The 
experiment was conducted in winter season. Brooding was performed in traditional system by using 100 watts electric bulbs and then heat was decreased gradually by lifting up the bulbs as per requirement of temperature. Thermohygrometer device was hanged with the brooder at bird's level to record temperature and relative humidity. After 14 days, the legbands were pulled out from leg and applied to wing. The chicks were brooded and reared up to 4 weeks of age in the brooder house and then distributed to the selected farmers, as described at earlier section.

\section{Feeding and watering of the experimental birds}

Commercial broiler feed purchased from the market was used for the feeding of experimental birds. For initial two weeks, starter feed (CP-20\%, ME-3000 Kcal $/ \mathrm{kg}$ ) was supplied, followed by broiler grower (CP-19\%, ME-3050 Kcal $/ \mathrm{kg}$ ) up to the end of experimental period (12 weeks). Feed was supplied twice daily; morning and afternoon. Fresh, cool and clean drinking water was made available for all the times. Feeders were cleaned twice in a week whereas drinkers were washed daily. Refusals of feed were measured daily in the morning. During brooding period (0-4weeks) ad-libitum feed were supplied to the chicks in confinement. In morning a total of $50 \mathrm{~g}$ feed/bird/day was supplied as supplementary feed to the birds during 5-12 weeks rearing at farmer's house under free range rearing.

\section{Litter management}

Good litter management is important as because it reduces the volume of ammonia. In Bangladesh, since the ambient temperature and relative humidity become too much high during summer (April to August), low quality litter and its poor management usually increased ammonia emission that may negatively impact on the overall performance of experimental birds. Therefore, necessary care was taken in selection of litter materials and its good management practices while the research trial was conducted. Fresh and dry rice husk was used as a litter material with a depth of about 4 $\mathrm{cm}$. Litter materials were stirred at 7 days interval, or even more frequently, if necessary. New rice husk was also added with the previous litter when necessary.

Fresh and dry rice husk was used as litter materials. When the birds were brought to farmer's house, litter materials were stirred at 7 days interval or even more frequently, if necessary. New rice husk was also added with the previous litter when necessary.

\section{Vaccination}

Routine vaccinations which are generally practiced for indigenous chicken up to 12 weeks of age were performed. In order to prevent New Castle disease, BCRDV (Baby Chick Ranikhet Disease Vaccine) was administered through intra ocular route at 3 days and 17 days of age as boosting dose followed by RDV (Ranikhet Disease Vaccine) at 60 days. Fowl pox vaccine was administered at 35 days of age.

\section{Data collection, record keeping and statistical analysis}

Data on weekly live weight and weight gain were recorded up to 12 weeks of age. Survivability was calculated based on the total number of dead birds recorded in each treatment group. Weekly feed consumption data was recorded and the efficiency of feed utilization was calculated based on the total feed consumption and weekly average body weight gain. Data recorded during the experimental period were analyzed using General Linear Model (GLM) procedures of SAS Institute (SAS, 2002) with $\mathrm{p}<0.01$ or $\mathrm{p}<0.05$ level of significance. All data were analyzed in completely randomized design. The Duncan's Least Significance Difference test was used to determine significant difference among treatment groups for various parameters considered in the experiment.

\section{Results and Discussion}

\section{Performance of four genotypes of indigenous chicken during brooding period of $(0-4$ weeks $)$ under complete
confinement}

The growth performances of four genotypes of indigenous chicken were shown into two phases. First, three BLRI improved genotypes $\left(T_{1}, T_{2}\right.$ and $\left.T_{3}\right)$ were kept together up to 4 weeks whereas, non-descriptive indigenous chicks $\left(T_{0}\right)$ were brooded separately. Table 1 shows the weekly performance of four indigenous chicken genotypes.

At the end of $4^{\text {th }}$ weeks, body weight of all four genotypes of experimental birds ranged between $184-224 \mathrm{~g} / \mathrm{bird}$ and weekly body weight gain was within 48-72 g/bird. Weekly feed consumption at $4^{\text {th }}$ week of age was within the range of 220-235 g/bird. The BLRI Improved Hilly and Improved Native Chicken utilized feed more efficiently with an average FCR of 3.26 and 3.31 , respectively. Out of four indigenous chicken genotypes, non-descriptive native had the poor efficiency of feed utilization $(F C R=4.58)$, which was almost close to the FCR of BLRI Improved Naked Neck Chicken.

\section{Performance of four genotypes of indigenous chicken during growing period of (5-12 weeks) under free range rearing}

The overall results of growth performance in terms of live body weight, body weight gain, feed consumption ( $\mathrm{g} / \mathrm{bird} /$ week) and efficiency of feed utilization of four genotypes of chicken are presented in Table 2. 
Table 1: Performance of four types of indigenous chicken during the brooding period (0-4 weeks)

\begin{tabular}{|c|c|c|c|c|c|}
\hline \multirow{2}{*}{$\begin{array}{c}\text { Paramet } \\
\text { ers }\end{array}$} & \multirow{2}{*}{$\begin{array}{c}\text { Age } \\
\text { in } \\
\text { wks }\end{array}$} & \multicolumn{4}{|c|}{ Treatments } \\
\hline & & $T_{0}$ & $\mathbf{T}_{1}$ & $\mathbf{T}_{2}$ & $\mathbf{T}_{3}$ \\
\hline \multirow{5}{*}{$\begin{array}{l}\text { Body } \\
\text { weight }\end{array}$} & Initial & 31 & 31 & 30 & 31 \\
\hline & $1^{\text {st }}$ & 46 & 47 & 50 & 50 \\
\hline & $2^{\text {nd }}$ & 72 & 82 & 83 & 73 \\
\hline & $3^{\text {rd }}$ & 136 & 143 & 152 & 137 \\
\hline & $4^{\text {th }}$ & 184 & 214 & 224 & 189 \\
\hline \multirow{4}{*}{$\begin{array}{l}\text { Body wt. } \\
\text { gain }\end{array}$} & $1^{\text {st }}$ & 15 & 16 & 20 & 19 \\
\hline & $2^{\text {nd }}$ & 26 & 35 & 33 & 23 \\
\hline & $3^{\text {rd }}$ & 64 & 61 & 69 & 64 \\
\hline & $4^{\text {th }}$ & 48 & 71 & 72 & 52 \\
\hline \multirow{4}{*}{$\begin{array}{l}\text { Feed } \\
\text { consumpt } \\
\text { ion }\end{array}$} & $1^{\text {st }}$ & 68 & 73 & 73 & 73 \\
\hline & $2^{\text {nd }}$ & 95 & 100 & 100 & 100 \\
\hline & $3^{\text {rd }}$ & 154 & 160 & 160 & 160 \\
\hline & $4^{\text {th }}$ & 220 & 235 & 235 & 235 \\
\hline \multirow{4}{*}{ FCR } & $1^{\text {st }}$ & 4.53 & 4.56 & 3.65 & 3.84 \\
\hline & $2^{\text {nd }}$ & 3.65 & 2.86 & 3.03 & 4.35 \\
\hline & $3^{\text {rd }}$ & 2.41 & 2.62 & 2.32 & 2.50 \\
\hline & $4^{\text {th }}$ & 4.58 & 3.31 & 3.26 & 4.52 \\
\hline \multirow{4}{*}{$\begin{array}{c}\text { Mortality } \\
\%\end{array}$} & $1^{\text {st }}$ & 4.41 & 3.7 & 2.87 & 3.43 \\
\hline & $2^{\text {nd }}$ & 4.6 & 0 & 2.74 & 3.43 \\
\hline & $3^{\text {rd }}$ & 0 & 0.3 & 3.38 & 1.06 \\
\hline & $4^{\text {th }}$ & 0.32 & 1.2 & 7.01 & 4.3 \\
\hline
\end{tabular}

$\mathrm{T}_{0}=$ non-descriptive native chicken (control group), $\mathrm{T}_{1}=\mathrm{BLRI}$ improved native chicken, $\mathrm{T}_{2}=\mathrm{BLRI}$ improved Hilly chicken, $T_{3}=$ BLRI improved Naked Neck chicken.

\section{Live body Weight}

The weekly live weight of four different types of indigenous chicken in scavenging system at different ages is shown in Table 3. Results of weekly body weight showed that the BLRI Improved Hilly Chicken compared to Nondescriptive Native with supplementary feeding free range rearing attained significantly higher body weight $(1110.7 \mathrm{~g})$ at the end of experiment followed by Improved Native (900.6 g) and Improved Naked Neck (831.1 g).

The lowest live weight however was found in common indigenous (734.1 g) which was significantly lower than any other treatment groups. Overall results of present study clearly indicated that the BLRI Improved Hilly chicken genotypes are better in body weight.

In recent paper Faruque et al. (2015) demonstrated weight of different types of indigenous chicken, where they mentioned that the Hilly Chicken had highest live weight (1110.7g). Sarker et al. (2014) also found that Indigenous Hilly birds were heavier than the other indigenous chicken groups such as Naked Neck or Non-descriptive Native. Previous published report by Khandoker (1993) mentioned the body weight of non-descriptive native was $475 \mathrm{~g}$ at 12 weeks of age, which is much lower than the observation of present study with Non-descriptive Native $(734.1 \mathrm{~g})$ at the same age.

\section{Live weight gain}

Weekly live weight gain ( $\mathrm{g} / \mathrm{b} / \mathrm{wk}$ ) of four different types of indigenous chicken namely Non-descriptive Native, BLRI Improved Native Chicken, BLRI improved Hilly, BLRI improved Naked Neck are given in Table 4. The results of weekly live weight gain of experimental birds were differed significantly $(p<0.01)$ among the four treatment groups from beginning to end of the experiment.

Table 2: Live weight, body weight gain, feed consumption ( $\mathrm{g} / \mathrm{bird}$ ) and efficiency of feed utilization of four indigenous chicken genotypes under free range rearing (5-12 weeks)

\begin{tabular}{lccccc}
\hline Parameters & $\mathbf{T}_{\mathbf{0}}$ & $\mathbf{T}_{\mathbf{1}}$ & $\mathbf{T}_{\mathbf{2}}$ & $\mathbf{T}_{\mathbf{3}}$ & $\begin{array}{c}\text { Level } \\
\text { of sig. }\end{array}$ \\
\hline $\begin{array}{l}\text { Initial body weight (g/bird) } \\
\text { (at 5 } 5^{\text {th }} \text { week of age) }\end{array}$ & $184.1^{\mathrm{b}} \pm 10.09$ & $214.9^{\mathrm{a}} \pm 9.16$ & $224.6^{\mathrm{a}} \pm 10.70$ & $189.6^{\mathrm{b}} \pm 8.65$ & $* *$ \\
Final body weight (g/bird) & $734.1^{\mathrm{d}} \pm 64.10$ & $900.6^{\mathrm{b}} \pm 58.60$ & $1110.7^{\mathrm{a}} \pm 64.90$ & $831.1^{\mathrm{c}} \pm 58.60$ & $* *$ \\
$\begin{array}{l}\text { Body weight gain at 12 } \\
\text { weeks (g/bird) }\end{array}$ & $550.0^{\mathrm{c}} \pm 57.62$ & $685.8^{\mathrm{b}} \pm 52.00$ & $886.1^{\mathrm{a}} \pm 67.90$ & $641.5^{\mathrm{b}} \pm 57.31$ & $* *$ \\
Feed consumption (g/bird) & $2666.1^{\mathrm{c}} \pm 4.70$ & $2674.6^{\mathrm{b}} \pm 2.70$ & $2697.0^{\mathrm{a}} \pm 3.90$ & $2668.1^{\mathrm{b}} \pm 3.00$ & $* *$ \\
Cumulative FCR & $4.9^{\mathrm{a}} \pm 0.53$ & $3.9^{\mathrm{b}} \pm 0.30$ & $3.0^{\mathrm{c}} \pm 0.24$ & $4.2^{\mathrm{b}} \pm 0.37$ & $* *$ \\
\hline
\end{tabular}

$\mathbf{a}, \mathbf{b}, \mathbf{c}, \mathbf{d}$ Means bearing uncommon superscripts in a row differ significantly. $* *=(P<0.01)$. $\mathrm{T}_{0}=$ nondescriptive native chicken (control group), $\mathrm{T}_{1}=$ BLRI improved native chicken, $\mathrm{T}_{2}=\mathrm{BLRI}$ improved Hilly chicken, $T_{3}=$ BLRI improved Naked Neck chicken. 
Growth and Carcass characteristics of Bangladeshi chicken

Table 3: Weekly live weight ( $\mathrm{g} / \mathrm{bird}$ ) of four types of indigenous chicken under free range rearing (5-12 weeks)

\begin{tabular}{ccccccc}
\hline $\begin{array}{c}\text { Age } \\
\text { (week) }\end{array}$ & $\mathbf{T}_{\mathbf{0}}$ & $\mathbf{T}_{\mathbf{1}}$ & \multicolumn{1}{c}{$\mathbf{T}_{\mathbf{2}}$} & $\mathbf{T}_{\mathbf{3}}$ & LSD & $\begin{array}{c}\text { Level } \\
\text { of sig. }\end{array}$ \\
\hline $\mathbf{5}$ & $234.00^{\mathrm{b}} \pm 6.85$ & $231.75^{\mathrm{b}} \pm 9.84$ & $245.75^{\mathrm{a}} \pm 12.24$ & $210.75^{\mathrm{c}} \pm 8.43$ & 9.22 & $* *$ \\
$\mathbf{6}$ & $318.25^{\mathrm{d}} \pm 14.67$ & $361.88^{\mathrm{b}} \pm 11.32$ & $407.63^{\mathrm{a}} \pm 6.14$ & $336.38^{\mathrm{c}} \pm 8.94$ & 10.37 & $* *$ \\
$\mathbf{7}$ & $375.75^{\mathrm{d}} \pm 15.12$ & $455.75^{\mathrm{b}} \pm 16.32$ & $525.75^{\mathrm{a}} \pm 9.24$ & $403.25^{\mathrm{c}} \pm 12.74$ & 13.15 & $* *$ \\
$\mathbf{8}$ & $450.00^{\mathrm{d}} \pm 22.48$ & $543.63^{\mathrm{b}} \pm 21.82$ & $632.75^{\mathrm{a}} \pm 16.99$ & $482.50^{\mathrm{c}} \pm 21.88$ & 20.19 & $* *$ \\
$\mathbf{9}$ & $530.25^{\mathrm{d}} \pm 29.36$ & $635.50^{\mathrm{b}} \pm 25.63$ & $725.00^{\mathrm{a}} \pm 23.52$ & $573.50^{\mathrm{c}} \pm 24.36$ & 24.93 & $* *$ \\
$\mathbf{1 0}$ & $614.63^{\mathrm{d}} \pm 36.33$ & $712.50^{\mathrm{b}} \pm 33.48$ & $828.25^{\mathrm{a}} \pm 31.40$ & $654.63^{\mathrm{c}} \pm 31.10$ & 32.01 & $* *$ \\
$\mathbf{1 1}$ & $665.00^{\mathrm{d}} \pm 48.23$ & $792.38^{\mathrm{b}} \pm 50.42$ & $972.00^{\mathrm{a}} \pm 52.13$ & $740.63^{\mathrm{c}} \pm 44.31$ & 47.18 & $* *$ \\
$\mathbf{1 2}$ & $734.13^{\mathrm{d}} \pm 64.91$ & $900.63^{\mathrm{b}} \pm 58.06$ & $1110.7^{\mathrm{a}} \pm 64.69$ & $831.13^{\mathrm{c}} \pm 58.96$ & 59.61 & $* *$ \\
\hline
\end{tabular}

$\mathbf{a}, \mathbf{b}, \mathbf{c}, \mathbf{d}$ Means bearing uncommon superscripts in a row differ significantly. $* *=(P<0.01) . T_{0}=$ non-descriptive native chicken (control group), $T_{1}=B L R I$ Improved Native Chicken, $T_{2}=B L R I$ Improved Hilly Chicken, $T_{3}=B L R I$ Improved Naked Neck Chicken

Table 4: Weekly live weight gain $(\mathrm{g} / \mathrm{b})$ of four types of indigenous chicken under free range rearing $(5-12$ weeks)

\begin{tabular}{|c|c|c|c|c|c|c|}
\hline $\begin{array}{c}\text { Age } \\
\text { (week) }\end{array}$ & $\mathbf{T}_{\mathbf{0}}$ & $\mathbf{T}_{\mathbf{1}}$ & $\mathbf{T}_{2}$ & $\mathbf{T}_{\mathbf{3}}$ & LSD & $\begin{array}{l}\text { Level } \\
\text { of sig. }\end{array}$ \\
\hline 5 & $49.88^{\mathrm{a}} \pm 5.08$ & $16.88^{\mathrm{c}} \pm 1.96$ & $21.13^{b} \pm 4.29$ & $21.13^{b} \pm 1.73$ & 3.45 & $* *$ \\
\hline 6 & $84.25^{c} \pm 9.27$ & $130.13^{b} \pm 6.92$ & $161.88^{\mathrm{a}} \pm 11.58$ & $125.63^{b} \pm 6.67$ & 8.53 & $* *$ \\
\hline 7 & $57.50^{d} \pm 2.67$ & $93.88^{\mathrm{b}} \pm 10.11$ & $118.13^{\mathrm{a}} \pm 11.84$ & $66.88^{\mathrm{c}} \pm 7.94$ & 8.53 & $* *$ \\
\hline 8 & $74.25^{\mathrm{c}} \pm 8.03$ & $87.88^{b} \pm 10.99$ & $107.00^{\mathrm{a}} \pm 8.88$ & $79.25^{\mathrm{bc}} \pm 10.05$ & 9.23 & $* *$ \\
\hline 9 & $80.25^{\mathrm{b}} \pm 9.19$ & $91.88^{\mathrm{a}} \pm 5.77$ & $92.25^{a} \pm 10.15$ & $91.00^{\mathrm{a}} \pm 6.09$ & 7.75 & $* *$ \\
\hline 10 & $84.38^{\mathrm{b}} \pm 10.18$ & $77.00^{b} \pm 14.75$ & $103.25^{\mathrm{a}} \pm 13.27$ & $81.13^{\mathrm{b}} \pm 13.12$ & 12.44 & $* *$ \\
\hline 11 & $50.38^{\mathrm{c}} \pm 17.66$ & $79.88^{\mathrm{b}} \pm 21.03$ & $143.75^{\mathrm{a}} \pm 36.24$ & $86.00^{b} \pm 15.78$ & 23.24 & $* *$ \\
\hline 12 & $69.13^{\mathrm{c}} \pm 25.81$ & $108.25^{b} \pm 13.71$ & $138.75^{\mathrm{a}} \pm 41.65$ & $90.50^{\mathrm{bc}} \pm 23.40$ & 27.04 & $* *$ \\
\hline \multicolumn{7}{|c|}{$\begin{array}{l}a, b, c, d \text { Means bearing uncommon superscripts in a row differ significantly. } * *=(P<.01) . T_{0}=\text { Non- } \\
\text { descriptive Native Chicken (control group), } T_{1}=\text { BLRI Improved Native Chicken, } T_{2}=B L R I \text { Improved Hilly } \\
\text { Chicken, } T_{3}=\text { BLRI Improved Naked Neck Chicken, Value indicate- mean } \pm \text { Standard deviation (SD) }\end{array}$} \\
\hline $\begin{array}{c}\text { Age } \\
\text { (week) }\end{array}$ & $\mathbf{T}_{0}$ & $\mathbf{T}_{1}$ & $\mathbf{T}_{\mathbf{2}}$ & $\mathbf{T}_{3}$ & LSD & $\begin{array}{l}\text { Level } \\
\text { of sig. }\end{array}$ \\
\hline 5 & $325.88^{\mathrm{c}} \pm 0.83$ & $327.25^{\mathrm{b}} \pm 1.28$ & $328.75^{\mathrm{a}} \pm 1.16$ & $326.25^{\mathrm{bc}} \pm 0.89$ & 1.02 & $* *$ \\
\hline 6 & $331.25^{\mathrm{b}} \pm 1.67$ & $332.25^{b} \pm 1.49$ & $334.75^{\mathrm{a}} \pm 1.04$ & $329.50^{\complement} \pm 1.60$ & 1.42 & $* *$ \\
\hline 7 & $329.25^{\mathrm{c}} \pm 2.05$ & $331.38^{b} \pm 1.51$ & $333.50^{\mathrm{a}} \pm 1.31$ & $329.75^{\mathrm{bc}} \pm 1.67$ & 1.60 & $* *$ \\
\hline 8 & $331.63^{\mathrm{b}} \pm 1.41$ & $331.88^{\mathrm{b}} \pm 1.36$ & $334.13^{\mathrm{a}} \pm 1.13$ & $331.38^{\mathrm{b}} \pm 1.69$ & 1.36 & $* *$ \\
\hline 9 & $335.25^{\mathrm{b}} \pm 2.12$ & $335.25^{b} \pm 1.04$ & $336.88^{\mathrm{a}} \pm 0.83$ & $334.50^{b} \pm 0.93$ & 1.29 & $* *$ \\
\hline 10 & $336.50^{\mathrm{b}} \pm 1.51$ & $337.50^{b} \pm 1.77$ & $339.50^{\mathrm{a}} \pm 1.20$ & $336.50^{b} \pm 1.60$ & 1.48 & $* *$ \\
\hline 11 & $337.50^{\mathrm{b}} \pm 1.85$ & $338.00^{b} \pm 2.33$ & $343.75^{\mathrm{a}} \pm 2.33$ & $338.88^{\mathrm{b}} \pm 1.55$ & 2.00 & $* *$ \\
\hline 12 & $338.88^{\mathrm{C}} \pm 1.89$ & $341.13^{\mathrm{b}} \pm 1.46$ & $345.75^{\mathrm{a}} \pm 1.75$ & $341.38^{\mathrm{b}} \pm 2.13$ & 1.76 & $* *$ \\
\hline Total & $2666.13^{\mathrm{c}} \pm 4.97$ & $2674.63^{b} \pm 2.67$ & $2697.00^{\mathrm{a}} \pm 3.9$ & $2668.13^{b} \pm 3.60$ & 3.67 & $* *$ \\
\hline
\end{tabular}

$\mathbf{a}, \mathbf{b}, \mathbf{c}, \mathbf{d}$ Means bearing uncommon superscripts in a row differ significantly. $* *=(P<0.01)$. $T_{0}$ - Non-descriptive Deshi Chicken, $T_{1}-$ BLRI Improved Native Chicken, $T_{2}-$ BLRI Improved Hilly Chicken, $T_{3}-$ BLRI Improved Naked Neck Chicken, Value indicate- mean \pm Standard Deviation (SD) 
Overall, the BLRI Improved Hilly Chicken showed best body weight gain $(138.75 \mathrm{~g} / \mathrm{b})$ during entire experimental period followed by BLRI Improved Native $(108.25 \mathrm{~g} / \mathrm{b})$ and Naked Neck $(90.50 \mathrm{~g} / \mathrm{b})$. The lowest weekly average weight gain however was found in Nondescriptive Native Chicken (69.13 g/b).

Rashid et al. (2004) reported that supplementation with $60 \mathrm{~g}$ feed daily to scavenging Non-descriptive Native hens $(p<0.01)$ improved body weight gain significantly compared to without supplementation. They mentioned weekly body weight gain of Naked Neck, Hilly and Nondescriptive Native at $8^{\text {th }}$ week of age were $41.16,43.19$ and $43.89 \mathrm{~g} / \mathrm{bird}$ respectively under intensive management which values are little bit lower than the current observation. Halima (2007) reported daily body weight gain from 5-8 weeks of age, the mean daily body weight gain ranged from $8.80 \mathrm{~g}$ in Gassay chicken population to $11.50 \mathrm{~g}$ in the Mecha chicken population in Ethiopia which agreed with the findings of present study. Even the results of body weight in Sonali (RIR $\times$ Fayoumi) pullets kept in semi- scavenging system supplemented with balanced diet had significantly higher body weight gain. In the present study, BLRI Improved Hilly genotypes showed best genetic potentiality in weekly body weight gain as compared to other genotypes considered which are in line with the findings of Hossen (2003) and Islam (2012).

So it is likely that the weekly body weight gain of genotypes of indigenous chickens and crossbred Sonali are significantly improved at scavenging rearing system with feed supplementation.

\section{Feed intake}

Weekly average feed intake ( $\mathrm{g} / \mathrm{bird}$ ) of the birds under different treatments is given in table 5 . The results of weekly feed intake differed significantly $(p<0.01)$ among four treatment groups from the beginning to the end of experiment. Feed consumption of all treatment groups was gradually increased. The average total feed intake was significantly higher in BLRI Improved Hilly Chicken (2697.00 g/bird) followed by BLRI Improved Native Chicken (2674.6 g/bird) and BLRI improved Naked Neck Chicken $(2668.1 \mathrm{~g} / \mathrm{bird})$. While, the lowest feed consumption was found in Non-descriptive Native Chicken (2666.1 g/bird), which was significantly $(p<0.01)$ lower than any other treatment groups. There was a trend to increasing feed consumption in BLRI improved Hilly birds during the whole experimental period.

In the present study, feed intakes of four indigenous chicken genotypes were gradually increased with the advancement of rearing period although it was slightly decreased in the $7^{\text {th }}$ week due to lower feed efficiency. Finding of the study is disagreed with Faruque et al. (2015) who conducted experiment with various indigenous chicken genotypes of Bangladesh and found a result of non-significant $(p>0.05)$ difference in total feed consumption. Yeasmin (2000) however found the daily feed intake of normal feathered indigenous birds under farm to be $33.95 \mathrm{~g} /$ day/bird during 12 weeks of age which was lower than the findings of the present study.

\section{Feed conversion ratio (FCR)}

Weekly feed conversion ratio of four genotypes of indigenous chicken is shown at table 6 . The results of weekly feed conversion ratio showed that there were significant difference $(p<0.01)$ among the four treatment groups. The best feed conversion ratio was observed in BLRI improved Hilly Chicken (2.85) while the highest value i.e. poor FCR was found in Nondescriptive Native Chicken (5.99) at the end of experiment.

Table 6: Feed conversion ratio of different types of indigenous chicken at different age

\begin{tabular}{ccccccc}
\hline $\begin{array}{c}\text { Age } \\
\text { (week) }\end{array}$ & \multicolumn{1}{c}{$\mathbf{T}_{\mathbf{0}}$} & \multicolumn{1}{c}{$\mathbf{T}_{\mathbf{1}}$} & \multicolumn{1}{c}{$\mathbf{T}_{\mathbf{2}}$} & $\mathbf{T}_{\mathbf{3}}$ & LSD & $\begin{array}{r}\text { Level } \\
\text { of sig. }\end{array}$ \\
\hline $\mathbf{5}$ & $6.59^{\mathrm{c}} \pm 0.7$ & $19.62^{\mathrm{a}} \pm 2.22$ & $16.19^{\mathrm{b}} \pm 3.54$ & $15.54^{\mathrm{b}} \pm 1.36$ & 2.15 & $* *$ \\
$\mathbf{6}$ & $3.97^{\mathrm{a}} \pm 0.4$ & $2.56^{\mathrm{b}} \pm 0.13$ & $2.08^{\mathrm{c}} \pm 0.15$ & $2.63^{\mathrm{b}} \pm 0.15$ & 0.24 & $* *$ \\
$\mathbf{7}$ & $5.74^{\mathrm{a}} \pm 0.25$ & $3.57^{\mathrm{c}} \pm 0.41$ & $2.85^{\mathrm{d}} \pm 0.29$ & $4.99^{\mathrm{b}} \pm 0.59$ & 0.39 & $* *$ \\
$\mathbf{8}$ & $4.51^{\mathrm{a}} \pm 0.50$ & $3.83^{\mathrm{b}} \pm 0.50$ & $3.14^{\mathrm{c}} \pm 0.27$ & $4.24^{\mathrm{ab}} \pm 0.52$ & 0.44 & $* *$ \\
$\mathbf{9}$ & $4.23^{\mathrm{a}} \pm 0.49$ & $3.66^{\mathrm{b}} \pm 0.26$ & $3.69^{\mathrm{b}} \pm 0.44$ & $3.69^{\mathrm{b}} \pm 0.25$ & 0.37 & $* *$ \\
$\mathbf{1 0}$ & $4.05^{\mathrm{ab}} \pm 0.57$ & $4.52^{\mathrm{a}} \pm 0.80$ & $3.33^{\mathrm{b}} \pm 0.40$ & $4.27^{\mathrm{a}} \pm 0.91$ & 0.68 & $* *$ \\
$\mathbf{1 1}$ & $7.48^{\mathrm{a}} \pm 2.67$ & $4.49^{\mathrm{b}} \pm 1.14$ & $2.54^{\mathrm{c}} \pm 0.70$ & $4.06^{\mathrm{bc}} \pm 0.78$ & 1.49 & $* *$ \\
$\mathbf{1 2}$ & $5.99^{\mathrm{a}} \pm 3.51$ & $3.20^{\mathrm{b}} \pm 0.40$ & $2.85^{\mathrm{b}} \pm 1.43$ & $4.06^{\mathrm{b}} \pm 1.31$ & 1.95 & $*$ \\
\hline
\end{tabular}

$\mathbf{a}, \mathbf{b}, \mathbf{c}, \mathbf{d}$ Means bearing uncommon superscripts in a row differ significantly. $* *=(P<0.01), *=(P<0.05), T_{0}-$ Nondescriptive deshi chicken, $\mathrm{T}_{1}-$ BLRI Improved Native Chicken, $\mathrm{T}_{2}-$ BLRI Improved Hilly Chicken, $\mathrm{T}_{3}-$ BLRI Improved Naked Neck Chicken, Value indicate- mean \pm Standard Deviation (SD) 
FCR of the rest two groups such as BLRI Improved Native Chicken and BLRI Improved Naked Neck chicken were 3.20 and 4.06 respectively. Growth rate affects feed conversion. At $5^{\text {th }}$ week due to sudden change of feed growth rate was very low and thus affected the feed conversion ratio.

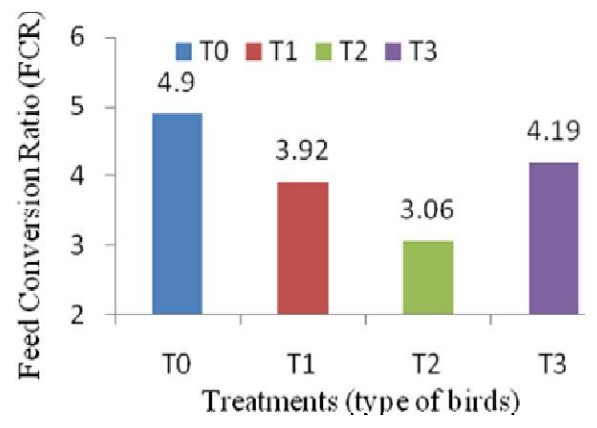

Fig. 1: Cumulative Feed conversion ratio of four types of indigenous chicken under scavenging system (5-12 weeks)

$T_{0}=$ Non-descriptive Native Chicken (control group), $\mathrm{T}_{1}=\mathrm{BLRI}$ Improved Native Chicken,
$\mathrm{T}_{2}=\mathrm{BLRI}$ Improved Hilly Chicken, $\mathrm{T}_{3}=$ BLRI Improved Naked Neck Chicken

Yeasmin (2000) reported the FCR value of 3.95 in normal feathered indigenous birds under farm condition during 12 weeks of age which is almost similar to the FCR of BLRI improved Naked Necked genotype. On the contrary of the of the results of present study, a non-significant $(p<0.01)$ difference in FCR were stated in recent report by Faruque et al. (2016) among the three native chicken genotypes namely nondescriptive native, Hilly, and Naked Neck. Khondoker (1993) found that the FCR of indigenous chicken at $12^{\text {th }}$ week was 5.38, which is very close to FCR of control i.e. nondescriptive native chicken. In present study, BLRI Improved Hilly Chicken attained the highest body weight with better gain and significantly higher efficiency in feed utilization $(F C R=2.85)$. Almost similar FCR (2.80) was reported by Rahman et al. (2013) for Hilly Chicken kept under intensive management system. The result coincides with Hossen (2003) who indicated that pullets reared in semi-scavenging system and supplemented with balanced feed showed better performance in feed conversion efficiency than the complete scavenging and supplementation with broken rice and soybean crushed.

Table 7: Carcass characteristics and meat yields of four types of indigenous chicken

\begin{tabular}{lccccc}
\hline \multicolumn{1}{c}{ Parameter } & \multicolumn{1}{c}{$\mathbf{T}_{\mathbf{0}}$} & $\mathbf{T}_{\mathbf{1}}$ & $\mathbf{T}_{\mathbf{2}}$ & $\mathbf{T}_{\mathbf{3}}$ & $\begin{array}{c}\text { Level } \\
\text { of sig. }\end{array}$ \\
\hline Live weight.(g) & $683.25^{\mathrm{b}} \pm 103.75$ & $740.75^{\mathrm{b}} \pm 159.75$ & $1180.38^{\mathrm{a}} \pm 183.68$ & $735.13^{\mathrm{b}} \pm 173.36$ & $* *$ \\
Dressing \% & $61.52^{\mathrm{c}} \pm 1.19$ & $64.87^{\mathrm{b}} \pm 1.90$ & $69.08^{\mathrm{a}} \pm 1.90$ & $64.61 .198^{\mathrm{b}} \pm 1.19$ & $* *$ \\
Breast meat \% & $10.00^{\mathrm{b}} \pm 1.31$ & $12.26^{\mathrm{ab}} \pm 2.29$ & $13.82^{\mathrm{a}} \pm 1.82$ & $12.82^{\mathrm{a}} \pm 3.69$ & $*$ \\
Thigh meat \% & $9.63^{\mathrm{b}} \pm .088$ & $13.63^{\mathrm{a}} \pm 3.05$ & $15.17^{\mathrm{a}} \pm 1.00$ & $14.07^{\mathrm{a}} \pm 0.88$ & $* *$ \\
Drumstick meat \% & $8.25^{\mathrm{b}} \pm 0.85$ & $13.52^{\mathrm{a}} \pm 0.74$ & $14.01^{\mathrm{a}} \pm 0.77$ & $13.43^{\mathrm{a}} \pm 0.93$ & $* *$ \\
Wing \% & $8.00^{\mathrm{b}} \pm 0.80$ & $9.13^{\mathrm{a}} \pm 0.91$ & $9.92^{\mathrm{a}} \pm 0.38$ & $9.41^{\mathrm{a}} \pm 0.92$ & $* *$ \\
Gizzard \% & $4.31^{\mathrm{ab}} \pm 0.38$ & $4.76^{\mathrm{a}} \pm 0.73$ & $3.93^{\mathrm{b}} \pm 0.68$ & $4.86^{\mathrm{a}} \pm 0.65$ & $*$ \\
Head \% & $4.03^{\mathrm{b}} \pm 0.27$ & $4.83^{\mathrm{a}} \pm 0.64$ & $4.59^{\mathrm{a}} \pm 0.36$ & $4.81^{\mathrm{a}} \pm 0.52$ & $* *$ \\
Neck \% & $3.88 \pm 0.32$ & $3.79 \pm 0.58$ & $4.01 \pm 0.84$ & $3.76 \pm 0.85$ & $\mathrm{NS}$ \\
Liver \% & $4.11 \pm 0.16$ & $4.37 \pm 0.97$ & $3.57 \pm 0.35$ & $4.07 \pm 0.43$ & $\mathrm{NS}$ \\
Heart \% & $0.61 \pm 0.05$ & $0.66 \pm 0.19$ & $0.61 \pm 0.09$ & $0.69 \pm 0.21$ & $\mathrm{NS}$ \\
\hline
\end{tabular}

$\mathbf{a}, \mathbf{b}, \mathbf{c}, \mathbf{d}$ Means bearing uncommon superscripts in a row differ significantly. $* *=(P<0.01), *=(P<0.05)$. NS $=$ Non-significant, $T_{0}=$ Non-descriptive Native Chicken (control group), $T_{1}=$ BLRI Improved Native Chicken, $T_{2}=B L R I$ Improved Hilly Chicken, $T_{3}=$ BLRI Improved Naked Neck Chicken 


\section{Survivability}

Overall survivability was $98.61 \%$. A total of four birds, two birds from each of the $T_{1}$ and $T_{3}$ were died during the entire experimental period. Among the four, two birds were killed by predators while for other two the reasons could not be ascertained. Statistical analysis showed no significant difference for survivability among the four genotypes of indigenous chicken. Faruque et al. (2016) found that survivability of Hilly and Naked Neck genotypes during growing period (5-12 weeks) were $93.11 \%$ and $95.34 \%$ respectively under intensive rearing.

In present study, better survivability found in all genotypes of indigenous chicken might be because of better brooding management, standard level of supplementation and optimization nutrients received both in confined and scavenging.

\section{Carcass characteristics}

The carcass characteristics and meat yields of four genotypes of indigenous chicken reared under free range system are shown in Table 7. In BLRI improved Hilly chicken, live weight $(1180.38 \mathrm{~g})$ and dressing percentage $(69.08 \%)$ were significantly higher than other remaining genotypes. Findings of present study agreed with the report of Rahman et al. (2013), who found native Hilly chicken have better potentiality for meat production. In present study, thigh meat, drumstick and wing meat percentage were significantly higher in BLRI improved Hilly, Naked Neck and native chicken as compared to non-descriptive native chicken. It was mentioned that the carcass yield of Naked Neck was better than the indigenous native chicken. No significant difference was however found among the four genotypes of indigenous chickens.

\section{Economic analysis}

Production cost was calculated by considering cost of bird, feed, labor, utilities, vaccines, medicine and other items involved. The results of cost benefit analysis for profit measurement of different type of indigenous chicken in free range system are shown in Table 8 . Total cost of production was almost similar in all treatments but net return/bird was higher in BLRI improved Hilly chicken BDT. 117.6 followed by BLRI Improved Native Chicken BDT. 105.4 and BLRI improved Naked Neck BDT. 81.6. While the lowest net return/bird was found in Non-descriptive Native in BDT. 48.9.
Table 8: Cost-benefit analysis of rearing four genotypes of indigenous chicken under free range system

\begin{tabular}{lrrrr}
\hline $\begin{array}{l}\text { Variables } \\
\text { (TK/chick) }\end{array}$ & \multicolumn{1}{c}{$\mathbf{T}_{\mathbf{0}}$} & \multicolumn{1}{c}{$\mathbf{T}_{\mathbf{1}}$} & \multicolumn{1}{c}{$\mathbf{T}_{\mathbf{2}}$} & \multicolumn{1}{c}{$\mathbf{T}_{\mathbf{3}}$} \\
\hline Feed cost & 107 & 108.6 & 109.4 & 108.2 \\
Chick cost & 36 & 36 & 36 & 36 \\
Labor cost & 30 & 30 & 30 & 30 \\
$\begin{array}{l}\text { Vaccination } \\
\text { cost/bird }\end{array}$ & 15 & 15 & 15 & 15 \\
Other cost & 20 & 20 & 20 & 20 \\
Total cost & 208 & 209.6 & 210.6 & 209.2 \\
Gross return & 256.9 & 315 & 388 & 290.8 \\
$\begin{array}{l}\text { Net return/bird } \\
\text { ret }\end{array}$ & 48.9 & 105.4 & 177.6 & 81.6 \\
$\begin{array}{l}\text { Net return } \\
\text { /kg }\end{array}$ & 66.60 & 117.11 & 159.89 & 98.17 \\
\hline
\end{tabular}

* Market price of live chicken -Tk.350 per kg

\section{Conclusion}

Out of four indigenous chicken genotypes, the BLRI improved Hilly showed better result in terms of body weight, efficiency of feed utilization and among the carcass traits yield studied. Economic returns on the cost of production were also better in Hilly chicken compared against all other three genotypes.

\section{Acknowledgement}

Authors are grateful to the Bangladesh Livestock Research Institute (BLRI) for the financial support from a project entitled "Poultry conservation and development project." Special thanks to the department of Poultry Science for the logistic supports.

\section{References}

Das SC, M Ahammed, SD Chowdhury and MA Ali (2014). Eggs for me, Eggs for you, Eggs for all. Keynote paper presented in the Seminar on "World's Egg Day 2014" held in 18 October, 2014 at BAU, Mymensingh, Bangladesh. Jointly organized by the Department of Poultry Science, Bangladesh Agricultural University, Mymensingh, and WPSA - Bangladesh Branch.

Das SC, SD Chowdhury, MA Khatun, M Nishibori, N Isobe and Y Yoshimura (2008). Poultry production profile and expected future projection in Bangladesh. World's Poultry Science Journal 53: 387-394

Faruque S, AKFH Bhuyian, MOA Rahman, MSK Sarker and NR Sarker (2016). Conservation and improvement of native chicken: Performance of fifth generation. Proceedings of a Seminar on Annual Research Review 
Workshop-2016. 2-4 November 2016, BLRI Conference Hall, $3^{\text {rd }}$ floor, Building-3. Bangladesh Livestock Research Institute, Savar, Dhaka. P. 17-18.

Faruque S, MN Islam and AKFH Bhuiyan (2015). Ex situ Improvement of Indigenous Chicken in Bangladesh. Tropical Agricultural Research 26(4):596 - 607.

Halima HM (2007). Phenotypic and genetic characterization of indigenous chicken population in Northwest Ethiopia. Ph. D thesis, submitted to the Faculty of Natural and Agricultural Sciences, Department of Animal, Wildlife and Grassland Sciences, University of the Free State, Bloemfontein, South Africa.

Hossen MJ (2003). Profitability by feed supplementation to crossbred chicks (sonali) under semi-scavenging system. M. Sc. Thesis, Department of Animal Science, Bangladesh Agricultural University, Mymensingh.

Islam F, SC Sarker, MNM Ibrahim, AM Okeyo, H Jianlin, MA Hoque and AKFH Bhuyian (2015). Effect of superior indigenous cocks on the performance of the progeny in rural villages of Bangladesh. Proceedings of $9^{\text {th }}$ Poultry Show and Seminar. p. 297-305.

Islam F, SC Sarker, AKFH Bhuiyan, M Akteruzzaman, RC Bett, I Baltenweck, J Poole, MNM Ibrahim and AM Okeyo (2012). The status of indigenous chicken farming \& options for improvement in Bangladesh. Proceedings of a Seminar, Animal Husbandry Faculty Gallery, Bangladesh Agricultural University, Mymensingh. p. 21.

Khondoker MAMY (1993). Performance of indigenous (deshi), Rhode Island Red (RIR) and desi X RIR chicken under farm condition. Thesis submitted to the Department of Poultry Science, Bangladesh Agricultural University, Mymensingh.

King Ori AM (2004). The protein and energy requirements of indigenous chickens (Gallus domesticus) of Kenya, (Ph.D. thesis. Egerton University, Kenya, p:93).

Mengesha M (2012). Indigenous Chicken Production and the Innate Characteristics. Asian Journal of Poultry Science 6(2):56-64.

Miah MY, SD Chowdhury, AKFH Bhuiyan and MS Ali (2014). Effect of different levels of dietary energy on growth performance of indigenous desi chicks reared in confinement up to target weight. Livestock Research for Rural Development 26(7):124
Norris D, JW Ng Ambi, Benyi, ML Makgahlela, HA Shemilis and K Nesamvuni (2007). Analysis of growth curves of indigenous male Venda and Naked Neck chickens. South African Journal of Animal Science 37(1): 21-26.

Rahman MM, S Faruque, MS Islam, MN Islam and MA Rashid (2013). Comparison of growth performance and meat yield of Hilly chicken under two feeding regimens. A Scientific Journal of Krishi Foundation 11(2): 38-43.

Rashid MM, MN Islam, BC Roy, K Jakobsen and C Lauridsen (2004). Effect of dietary supplementation of energy and protein on production performance and egg quality of scavenging crossbred hens in rural areas under tropical condition. Livestock Research for Rural Development 16:63.

Sarker NR, A Hoque, S Faruque, N Islam and AKFH Bhuiyan (2014). An ex situ study on body characteristics and effect of plumage color on body weight of indigenous chicken (Gallus domesticus) in Bangladesh. Acta Scientiarum. Animal Sciences 36 (1):79-84

SAS Institue Inc. (2002).SAS/STAT version 9.0. User's Guide. SAS Inst. Inc., Cary, NC, USA.

Singh DP and JC Fotsa (2011). Opportunities of poultry breeding programmes for family production in developing countries: The bird for the poor. E-conference of the International Network for Family Poultry Development in collaboration with FAO and supported by the International Fund for Agricultural Development (IFAD) 24 January - 18 February 2011.

Sonaiya EB and SEJ Swan (2004). Small-scale poultry production. Technical guide FAO 2004. P.13-23.

Swatson HK, IV Nsahlai and BK Byebwa (2001). The status of smallholder poultry production in the Alfred District of KZN (South Africa): Priorities for intervention. Proceedings of the Institutions for Tropical Veterinary Medicine, 10th International Conference on Livestock, Community and Environment, 20-23rd August 2001, Copenhagen, Denmark.

Yeasmin T (2000). Effect of incorporating dwarf gene from indigenous (desi) to exotic breeds of chicken. Ph. D. Thesis, Department of Poultry Science, Bangladesh Agricultural University, Mymensingh. 